\title{
Incremental Innovation towards Business Performance: Data Management Challenges in Healthcare Industry in Indonesia
}

\author{
Muharman Lubis ${ }^{1, \mathrm{a}}$, Arif Ridho Lubis ${ }^{2}$, Bastian Lubis ${ }^{3}$ and Asmin Lubis ${ }^{3}$ \\ ${ }^{1}$ School of Industrial Engineerin, Telkom University, Bandung, Indonesia \\ ${ }^{2}$ Department of Computer Engineering and Informatics, Politeknik Negeri Medan, Indonesia \\ ${ }^{3}$ Department of Anesthesiology and Reanimation, Universitas Sumatera Utara, Indonesia
}

\begin{abstract}
The Industry 4.0 indicate the increases in competitive pressures, the margins reduction, the availability of new technology and the marketing development techniques suggest making more complex decisions to make and sustain the success. Data management is essential for organizations because the administrative process, which data is acquired, validated, stored, protected and processed through its accessibility, reliability and timeliness ensures that the needs of data are met. It is also a process of developing data architectures, practices and procedures that address the data and then implement these aspects on a regular basis. All these process will ease and smoothen the business flow. Therefore, there are number of data management challenges to maintain sheer volume of data, taking reactive approach, lack of process and data handling, fragmented data ownership and driving a data culture. This study investigate the current issues in health industry to overcome through recognizing both the importance of quality data and having more sophisticated approach to manage data as the organization begin shifting to be more data centric model.
\end{abstract}

\section{Introduction}

The definitions of innovation for medical products may not be sufficient to evaluate medical devices and system. The characteristics that drive innovation are largely different, which the current standards and thresholds for capturing the added benefit of innovative molecules may not be representative of the marginal utility produced by other medical technologies [1]. According to data from the Ministry of Health, there are a total of 2,457 hospitals in Indonesia currently. The increase in private hospitals, both profit and non-profit has grown faster and now outnumber the number of public hospitals with $61 \%$ market share [2]. Meanwhile, at around $70 \%$ of hospitals are governmental hospitals, which hospital care services accounted for $60 \%$ of total healthcare expenditure [3]. Nowadays, organized data, systematic data retrieval and storing loads of data are crucial subject to every hospital, even to every organization, especially for large enterprises that deal with large number of data and clients' information like hospital, government body and administration department. An

${ }^{\text {a } C o r r e s p o n d i n g ~ a u t h o r: ~ m u h a r m a n l u b i s @ t e l k o m u n i v e r i s t y . a c . i d ~}$ 
innovation should bring agility on every autonomous implemented idea which further clubbed together based on symmetric behavioral pattern and business needs customization to formalize a radical innovation thus continuing the ideation and implementation cycle. A prelude to evaluate the quality of the data and the context of use is largely unknown, because the ability to assess has been offered in the generic manner [4].

Indonesia's healthcare expenditure at $2.9 \%$ of GDP is one of the lowest in the region and below ASEAN countries' average of $4 \%$, despite growing at $14 \%$ for the last five years [2]. In the process of doing business in Indusrty 4.0, the organization will involve certain procedures, policies, regulations and problems based on the sector involved, with aligning to the customer expectations satisfaction. However, data management is one of the important solutions that require great attention from the organization to support the commercial process in terms of analysis and development. Therefore, the hospital collects many interrelated data, such as when the patient received treatment, medication, theraphy, medical condition, dose of medicine, patient diagnosis and information, medical examination, check-ups, etc. They need to be done immediately and accurately where data collection and storage process should be integrated from paper-based into digital-based record for comprehensive information retrieval and worst incident avoidance to develop database center or even data warehouse [5]. Furthermore, the changes in regulations such as negative investment lists, patents, price ceilings and anti-trusts should impact the pharmaceutical industry as a whole [2], so the health standard always developed reactively and take long time to be implemented. Therefore, innovation is required to overcome issues and challenges in the health industry, so the understanding of their characteristics can provide more insight to improve the service delivery and data management such as several criterion below.

Table 1. Innovation criterion for differences

\begin{tabular}{|l|l|l|l|l|l|}
\hline No & Innovation Matrix & Incremental & Responsive & Disruptive & Radical \\
\hline 1. & $\begin{array}{l}\text { Organizational } \\
\text { Strategy }\end{array}$ & Bottom-up & Top-Down & Indirect & Direct \\
\hline 2. & Market Type & Low & Closed & Open & High \\
\hline 3. & Learning Curves & Slow & Trial & Quick & Paradox \\
\hline 4. & Value Creation & Followers & Collaborative & Partnership & Pioneer \\
\hline 5. & $\begin{array}{l}\text { Product/Service } \\
\text { Improvement }\end{array}$ & Minor & Major & Significant & Trivial \\
\hline 6. & Purposes & Simplification & Expansion & Penetration & Replacement \\
\hline 7. & Discovery Approach & Modification & Reflective & Insights & Metamorphosis \\
\hline 8. & Enhancement & Existing Platform & End Result & Acknowledgement & Component Delivery \\
\hline 9. & Research Source & Consolidation & Performance & Brainstorming & Re-conceptualization \\
\hline 10. & Business Process & Refinement & Exploration & Transformation & Elimination \\
\hline 11. & Changes & Constant & Phases & Rapid & Risky \\
\hline 12. & Achievement Goals & Productivity & Representational & Exponential & Opportunities \\
\hline 13. & Delivery Objective & Retention & Loyalty & Satisfaction & Potential \\
\hline 14. & General Operation & Packaging & $\begin{array}{l}\text { Distinguished } \\
\text { Features }\end{array}$ & Price Wars & $\begin{array}{l}\text { Product/Service } \\
\text { Inception }\end{array}$ \\
\hline 15. & Measurement & User Comforts & Added Value & Substantial Value & $\begin{array}{l}\text { Competitive } \\
\text { Advantages }\end{array}$ \\
\hline 16. & Evaluation Instrument & $\begin{array}{l}\text { Financial } \\
\text { Resources }\end{array}$ & $\begin{array}{l}\text { Human } \\
\text { Resources }\end{array}$ & Access Resources & Demand Resources \\
\hline
\end{tabular}

\section{Literature review}

\subsection{Data Accuracy}

Identification of five hospitals in Indonesia that has been using Hospital Information System (HIS) to handle their health record management, presented numerous issues that 
could lead to inaccurate data about patient information. For example many data in the form of physical copy, the lack of Internet infrastructure in each health division, high computer illiteracy in technical staff to operate and troubleshoot certain features in HIS, less interest to adopt digital approach, little socialization and training to relevant staff and inappropriate utility in term of electricity, backup, recovery, compression and antivirus [6]. At certain extent, the inaccuracy of data can hinder the doctors to diagnose the type of disease from patient, prevent the cross-validate data to produce fast decision making and suggest unspecific medicine that no longer as the treatment process. It estimates approximately the range of $0.5-30 \%$ errors or tiny to small differences in the databases could compromise the decision making process that might endanger the patient long term condition [7]. After registration in particular Policlinic and Posyandu, commonly patients are directed to the respected poly according to their illness or disease. Prior, they are registered into the register book in each poly, which data integrity has been less considered because every staff or other unknown people can have opportunity to change or even manipulate data indirectly or directly without notification over its entire life cycle [8].

In other context, there are also some internal management activities that do not obey the rules such as the regulation to govern hazardous waste management that has been enacted since 1999, but most of healthcare facilities have not yet complied. Although, in May 2008, the Indonesian government enacted a new Act of Solid Waste Management with the Act $18 / 2008$, which is followed by more technical regulations and policies on how to implement waste generators. Indeed, there is also other regulation to guide the process like the Ministerial Health Decree No 1204/2004 concerning Environmental Health Standards, still the disobedience have been found regularly due to the lack of the enforcement [9]. Unfortunately, out of 75 hospitals to be investigated, only 45 hospitals $(60.0 \%)$ have a sanitation unit, which can be assumed that missing information exist in the hospital in the managerial aspect especially in regard to procedure to throw away the garbage or waste after treatment service has been done [9]. Furthermore, the problem occur as there is no record at all in regard these medical waste due to the lack of documentation and platform. Actually, the information sharing mechanism between relevant unit can increases the productivity but has been done manually which tend to be forgotten during the process. Thus, the health industry should concern to eliminate the missing data and reducing overlapping of data that might also occur in term of consent and clarity to be given to the patients as there are lack of operational standard [10]. Meanwhile, basis data is prepared to overcome data inconsistency, data redundancy, data isolation, data duplication, data dependency and data accessibility by developing the uniqueness of data format and data type, while in particular hospital still use notes or excel to record the patient data, the list of operation schedule and the responsibility of the doctors [11]. Hence, $90 \%$ of raw materials for medicines in Indonesia are imported from faraway countries, which between the end of 2012 and now, the IDR has depreciated by a staggering $40 \%$ increase the price of medicine at higher cost [2]. The changes and the dependency of the imported medicine should be recorded accurately to identify the proper strategy to be made in solving the issue of the expensive price in hospital and drugstore.

\subsection{Data Entry}

In general, data collection of outpatient still used manual records, which often officers or staff make mistake and error in entry the data such as name and address, to some extent they even forget to input the whole data due to number of patient for intensive care due to emergency [12]. The complex cases of a new variable system of third-party actions have become other obstacles in the health information system. Historical data shows that the hospital still conserves large quantities of manual stocks or physical documents [13]. 
Surprisingly, employers' associations, business halls and even a number of government officials rejected the mandatory component of integrating national identity into the HIS as the lack of coordination between national hospital delay the medical treatment [14]. Multiple and mutual factors lead to invalid and inaccuracies data in the entry process, for instance person's attitude and behavior, lacking the technical skill and understanding, bad intention to hide some information, the improper interface, computer performance, personal mood, etc. After the adoption of the drug for sale, companies usually collect information about their products to ensure safety and quality, which is generally considered as the last phase of the innovation cycle as post-marketing surveillance [15] but the problem can arises as there is no monitoring procedure to keep track the patient location as the climate, eating and sleep order can influence the results against the success clinical trial in the lab. Normally, changes in patient or employee data must be determined first before the system development process begins. The marital status, the treatment method, the identification number, the patient's address, the passport number, the telephone number and the primary email are the kind of value that can change over time. Individual may be once in a single status but got married next time but the data value in the system still stores the old one. The data is valid, but the changes might affect the decision making or tracking process. On the other hand, there is also no mechanism to track and locate the origin of the data services organized by hospitals include inpatient, outpatient, emergency, referral and support after long period of time. Study to 28 hospital pharmacists found that there was much dissatisfaction with current pharmaceutical policy and participants recommended the need for improvement in the relevant regulations, which government should strictly regulate medicine prices and distribution in the market [3].

In some cases, a drug compound may not have regulatory approval to use for certain indicator but not the others. Actually, the failures in research of pharmaceutical compounds that do not meet the standards and unsuccessful to become commercialized products can provide useful information for future research. In fact, the failure rates of small molecule and biotherapeutic products are approximately $86 \%$ and $96 \%$ respectively. As the drug classes utilize new physiological pathways, future research is expected to reveal new uses for existing compounds [13-16]. The long process of exploration requires the uniqueness of data to prevent data redundancy with similar attribute such as in the model simulation and therapy process. Another risk to highlight to meet the requirements of industry 4.0 is related to the impact of Act no. 33/2014 that is effective since 17 Oct 2014 on Halal Product assurance. It requires all pharmaceutical products to be Halal certified by 2019. Naturally, there is around $90 \%$ of raw materials are imported, which is virtually extremely difficult for pharmaceutical companies to obtain the certification [2]. Meanwhile, the operational challenges has been identified in regard to the project scalability, which are small coverage in area and short term goal [7]. On the other hand, three main problem related the inventory management practice has been identified such as overstock, unjustified forecasting technique and lack of the IT support [13]. Commonly, it is reported that lacks of disabled parking areas, the absence of wheelchair accessible ramps and lack of elevators become the external factors including poor design, inadequate examination and improper equipment that make healthcare services inaccessible for people with limited mobility and hearing disabilities [14], in the end raise complex problem in data management.

\section{Research methodology}

This study use grounded theory to investigate the existing problem face by healthcare industry through methodic gathering and data analysis. It is started through simple questions of the current implementation of data management in healthcare industry. Then, 
the repeated ideas, concepts or elements are tagged with codes to be reviewed to extract new information. Meanwhile, it also use prior literature review in journals, conference proceedings, theses and articles of expert author. For data collection, health websites and public repositories are examined as well as the respected database including IEEE, Springer, ACM and Science Direct are explored and research paper within 10 years are studied to expand the scope of understanding in term of historical attempts. Across the great variety of illnesses, patients and their families are often confronted with similar types of problems. The site targets people who know about the daily troubles of rare disease patients whether that is the patient himself or other people connected to patients.

\section{Fixing data problem}

The lack of a common understanding of how data quality is quantified lead become prohibitive factor to exploit data accuracy lead to isolated process and partial measures taken over a period of time within the open data community [4]. Different system integration is required to provide the automatic cooperation and coordination between each organization and related institution such as regulator, health department, CRO (contract research organization), hospital, drug laboratory, clinics and university [7]. On the other hand, the cost of outsourcing can be estimated by setting the size of data storage space (TB) or number of data or images by using the clearance system to verify and validate the completeness and correctness of data. It is necessary to keep the updated information remain clear and accurate although be handled by different unit or division. The system is embedded in the HIS that accept the data sent by relevant staff periodically should be through proper check mechanism and strict authorization structure. Thus, the security procedure need to be matched with the readiness of system involving the user, activities, structure and technology in the observed environment [17]. Furthermore, there are number of regulation with specific issues have been enacted by legislative over decades that might have different principles, attributes and consideration lead to different interpretation in the court, which complicate the citizen even certain legal experts to understand the regulation [18]. However, intensive regulation that codifies an industry's past can pose a significant barrier to incremental innovator who are trying to improve on entrenched the traditional or conventional business [19].

In general, low metadata quality will affect the satisfaction about the service introduced by digital libraries. Automated metadata tools can be implemented in HIS to produce some alerts for the low quality record. The provision of earlier treatment can reduce the health costs and can eliminate the risk of chronic diseases [20]. Therefore, incremental innovation is the attempt to heighten the existing therapeutic classes by improving complex molecular structures, reformulating medicines to enchance patient administration, adding the number of available dose options, discovering new physiological interactions of known medicines, exploring new uses for existing medicines and replenishing other properties of existing medicines. It is often based on the experiences of healthcare providers and patients' needs. Prevention is always better than cure, which the advances of Big Data analytics, it is easy to capture, analyze and compare patient symptoms earlier to offer a preventive care in a better way. Clear strategy that aims and visions communicated vigorously, bottom-up innovations facilitated and funded at a considerable scale and an innovation center orchestrating, fueling, and reflecting the processes of change, these are the main ingredients to produce constant changes for incremental innovation strategy [15]. Studies of gender in the health sciences may show potential for development when viewed against the medical model of health and disability, which are unavoidably connected with poverty, inaccessible education, inadequate healthcare services and inability to access health information and employment due to discrimination on the grounds of gender and disability [9, 21]. Big data 
can more accurately pinpoint where education and prevention is needed to produce healthier populations at lower costs [20].

\section{Conclusion}

Medical data must be kept as a reference for up to 20 to 30 years, which consumed a lot money, time and effort due to its difficulty to maintain and highly risk for long-term digital data management. In the process of data storage and monitoring, the total cost account for data management in the long term, with all the tasks necessary to maintain minimum levels of service. It is also taking into account the additional limitations, such as data security, privacy protection, retention and the seamless connection to allow fluid communication within the current system. Incremental innovations can provide advances drugs through the expansion of therapeutic classes, increasing the number of available dose options, discovering new physiological reactions and improving other properties of the existing drugs. Once the new drug is introduced, the important knowledge of health care providers during the "post-marketing monitoring" phase helps researchers to identify the needs of unattended patients. This kind of innovation ranges from design modifications to the complex molecular structures. However, there may be the complexity in the improvements process but the overall goal of further innovation remains the same, which is related to the increases the number of treatment options available to patients.

\section{References}

1. C. Oriana, A. Patrizio, B.P. Roberta, C. Marianna, J. Claudio, T. Rosanna. "De innovation: The concept of innovation for medical technologies and its implicaitons for healthcare policy-making". Health Policy and Technology, 5: 47-64, (2016).

2. E.A. Tanuwijaya. "Indonesia Industry Focus: Indonesia Healthcare Sector." DBS Group Research, (26 Nov 2015).

3. V. Gones. "Hospital pharmacy management: Australian and Indonesian perspectives." Thesis, University of Sydney, (2016).

4. H. Setiaji, F. Wahid. "Masalah implementasi sistem informasi rumah sakit: pelajaran dari beberapa proyek." Seminar Nasional Informatika Medis, p. 97, (2015).

5. A. Harsono. "Analisis implementasi sistem informasi manajemen rumah sakit umum daerah (SIM-RSUD) terintegrasi di provinsi Kalimantan Barat.” Eksplora Informatika, 5(1), 11-22, (2015).

6. S. Sadiq and M. Indulska. "Open data: quality over quantity." Int. J. of Information Management, 37, 150-154, (2017).

7. M. Lubis and M. Kartiwi. "Data management challenges in pharmaceutical industry." IIUM Press. Kuala Lumpur. ISBN 978-967- 4180-84-3 in M. Kartiwi and M.Z.M Akram, eds. Data management: issues, challenges and opportunities, (2011).

8. Iswahyudi, V. Sahfitri, S.D. Purnamasari. "Analisis dan perancangan basis data pasien rawat jalan pada rumah sakit Dr. Ibnu Sutowo Baturaja." Skripsi, Bina Darma, 2013.E.N.

9. S. Irianti. "Current status and future challenges of healthcare waste management in Indonesia." Media Litbangkes, 23(2), 73-81, (2013).

10. C.P.D. Yunita, C.T. Punami, Y. Dharmawan. "Evaluasi kegiatan manajemen sensus harian rawat inap rumah sakit umum daerah Banyumas tahun 2011.” Jurnal Kesehatan Masyarakat, 1(2), 143-153, (2012). 
11. Huda. "Desain basis data administrasi rawat inap pada rumah sakit bhayangkara akademi kepolisian Semarang." Skripsi, UDINUS, (2013).

12. Sucipto and I.U. Wardati. "Sistem informasi pendataan pasien pada rumah bersalin dan balai pengobatan pelayanan kesejahteraan umat (PKU) Muhammadiyah Batuwarno." Indonesian J. on Networking and Security, vol. 4(2), 27-32, (2015)

13. I.N. Rachmania and M.H. Basri. "Pharmaceutical inventory management issues in hospital supply chains." Management, 3(1), 1-5, (2013).

14. H. Thabrany. "Politics of national health insurance of Indonesia: a new era of Universal coverage." European Conference on Health Economics, NHI Indonesia, (2008).

15. E. Mohr. "Incremental innovations: changing the culture of teaching and learning." Educause Review, (September/October 2007).

16. Supeno, D. Novita and F. Prihatini. "Sistem informasi rekam medik unit kebidanan dan kandungan pad rumah sakit ibu dan anak Widiyanti Palembang." Skripsi, STMIK GI MDP, (2014).

17. A.R. Ahlan, M. Lubis and A.R. Lubis. "Information security awareness at the knowledge-based institution: its antecedents and measures." Procedia Computer Science 72, pp. 361-373, (2015).

18. M. Lubis, M. Kartiwi and S. Zulhuda."Current state of personal data protection in electronic voting: criteria and indicator for effective implementation." Telkomnika, 16(1), 290-301.

19. E. Kregor. "Food trucks, incremental innovation and regulatory ruts." 82 University of Chicago Law Review Dialogue 1, (2015).

20. S. Patel and A. Patel. "A big data revolution in healthcare sector: opportunities, challenges and technological advancements." Int. J. of Information Sciences and Techniques (IJIST), vol. 6, no. 1/2, (2016).

21. S. Kamal. "Pengolahan data rekam medis rumah sakit menggunakan pemograman visual foxpro-9.” Majalah Ilmiah, 24(1), 114-120, (2017). 